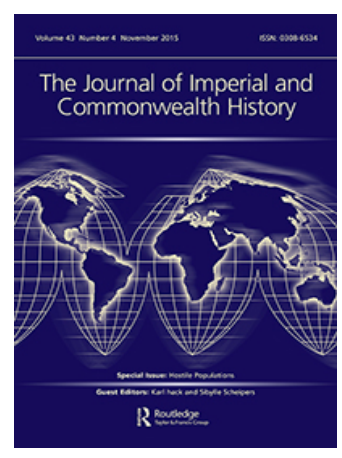

The Journal of Imperial and Commonwealth History

\title{
Terror in Galilee: British-Jewish Collaboration and the Special Night Squads in Palestine during the Arab Revolt, 1938-39
}

\section{Matthew Hughes}

To cite this article: Matthew Hughes (2015) Terror in Galilee: British-Jewish Collaboration and the Special Night Squads in Palestine during the Arab Revolt, 1938-39, The Journal of Imperial and Commonwealth History, 43:4, 590-610, DOI: 10.1080/03086534.2015.1083220

To link to this article: http://dx.doi.org/10.1080/03086534.2015.1083220

$$
\begin{aligned}
& \text { (c) } 2015 \text { The Author(s). Published by Taylor \& } \\
& \text { Francis. }
\end{aligned}
$$

\section{Published online: 04 Sep 2015.}

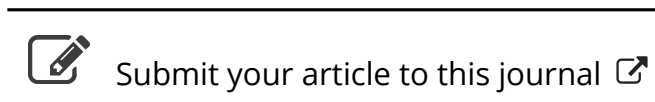

Џll Article views: 482

Q View related articles $\sqsubset$

View Crossmark data ¿ 


\title{
Terror in Galilee: British-Jewish Collaboration and the Special Night Squads in Palestine during the Arab Revolt, 1938-39
}

\author{
Matthew Hughes
}

In 1938 in British Mandate Palestine, British army officer Orde Wingate organised and led a joint British-Jewish military unit, the Special Night Squads (SNSs), to defeat Palestinian rebels fighting against British rule and Jewish immigration to Palestine during the Arab revolt, 1936-39. The SNSs operated in Galilee in northern Palestine. While biographies of Wingate cover his service in Palestine with the squads, this article extends the existing literature with an empirical examination of the operations of the SNSs based on a deep mining of British and Hebrew-language archival sources. This study argues that joint intelligence gathering operations introduced the British army to Jewish agents and the possibilities of collaboration-Wingate was an intelligence officer-before detailing combined military operations in the field with the irregular SNSs. The originality of this article comes from its dissection of how British soldiers brutalised Jewish troops by training them in well-established British counterinsurgency methods that targeted civilians and villages close to rebel attacks. Away from the control of established British military chains of command, the SNSs were especially tough in their war with Palestinians and they fought a 'dirty war', an operational method absorbed and normalised by Jewish soldiers serving under British command. This article is a military and imperial history that details the quotidian brutality of pacification, opens up wider debates on how imperial powers collaborated with loyalist colonial minorities, shows how regular armies used irregular forces in pacification campaigns and suggests that post-colonial regimes such as Israel carried over such methods of control.

Correspondence to: Matthew Hughes, Department of Politics and History, Brunel University, Uxbridge, UB8 3PH, UK. Email: matthew.hughes@brunel.ac.uk 


\section{Introduction}

When the British army deployed to Palestine in April 1936 at the start of the Arab revolt against British colonial rule and Jewish immigration to the country, it collaborated with the Jewish settlers there as a 'loyalist' force against Palestinian insurgents. The army readily turned to minority communities for colonial control, to recruit as soldiers, divide its enemies and to gather intelligence: Sikhs and Gurkhas in India, or after 1945 Turkish Cypriots, aboriginal trackers in Malaya, Kikuyu loyalists in Kenya and Protestants in Ireland. ${ }^{1}$ Jewish military collaboration with the British army is the subject of this article, leaving aside the recruitment by the colonial government of thousands of extra Jewish settlement and supernumerary police, almost 15,000 according to one source. ${ }^{2}$ Army-Jewish collaboration started with shared intelligence gathering, a combination that morphed into joint military units, notably the unconventional Special Night Squads (SNSs) that fought in Galilee in northern Palestine in 1938-39 and were led by the Nazareth-based British Army intelligence officer Captain Orde Wingate, a dedicated (Christian) Zionist who died in Burma in 1944 leading irregular forces against the Japanese. British commitment to the SNSs initially took the form of three platoons of 37 British soldiers based in Jewish settlements such as Hanita and Ein Harod and commanded by three subalterns seconded from Brigadier John Evetts' Haifa-based 16th Brigade: Lieutenants Mike Grove (Queen's Own Royal West Kent Regiment), Robert 'Rex' King-Clark (Manchester Regiment) and H. E. N. 'Bala' Bredin (Royal Ulster Rifles). ${ }^{3}$ Evetts had 'encouraged' Wingate to reconnoitre Galilee and draw up a 'detailed plan' for the 'establishment of Jewish counterinsurgency units which would operate at night with the support of British troops .... The policy had the blessing of Force Headquarters in Jerusalem but because it was considered to be an irregular practice few papers ever mentioned it. ${ }^{4}$ Wingate led patrols and was wounded doing so at the village of Dabburiyya in July 1938. Large numbers of Jewish soldiers from the Zionist defence organisation Haganah (The Defence) keen to get formal military training from the British passed through the SNSs, including many future Israeli commanders such as Yigal Allon and Moshe Dayan. Haganah became the Israeli army in 1948.

The supreme general officer commanding (GOC) in Palestine in early 1938, General Archibald Wavell, had lent his support to Wingate, but his successor, General Robert Haining, and the high command in Jerusalem were uncomfortable with unconventional warfare and the army eventually demanded Wingate's departure from Palestine in October 1938, spurred on by reports of SNS brutality. Command of the SNSs then passed to Bredin. When Wingate returned in December 1938, it was to a desk job and he had no access to secret papers, not least to stop him leaking documents to Jewish friends, which Wingate did little to hide. ${ }^{5}$ The British disbanded the last squad in July 1939. ${ }^{6}$ The SNSs prompted 'night' action elsewhere. The West Yorkshire Regiment ran its own 'special night squads', although it is not clear from the battalion intelligence summaries if these included Jewish soldiers or not. ${ }^{7}$ Meanwhile, the Jewish Tel Aviv municipal authority asked the British in August 1938 if it could form 'so-called night squads': 'The Jewish population of the South will be as ready as that of the 
North to provide the requisite number of men of good quality to take part in the offensive operations of this kind.8 ${ }^{, 8}$ These enterprises faded with Wingate's departure from Palestine.

This study of the SNSs argues that tough, often brutal, exemplary action was standard military counterinsurgency practice for the British soldiers leading the SNSs, easily employed by them against local civilians and insurgents, and then passed on to Jewish soldiers training and fighting with the unit. British military counter-rebel practice and doctrine had always been harsh and openly targeted civilians but soldiers' humanity, civil oversight, legal strictures, public and press scrutiny, rebel countermeasures and the colonial state's hierarchy of race-with 'white' insurgents usually treated less harshly-mitigated military action. ${ }^{9}$ Moreover, soldiers rotated through Palestine on time-bounded regimental tours of duty on what was for them another interesting colonial posting and they were not interested in the country's fate and so had no personal animosity for Palestinians beyond their being in revolt. When asked whether he or his men knew anything about Palestine before shipping out from the UK in 1938, King-Clark remembered in his memoirs how 'at that time, in the Army at least there was almost total indifference in and ignorance of political affairs - among the younger officers and men, anyway. ${ }^{10}$ This was not the case with the independently minded SNSs. The mercurial Wingate was a fanatical supporter of a Jewish state and he filled the SNSs with Jewish soldiers training for a future war of survival against the local Palestinians, which would come in 1948. This, alongside the lack of a formal military chain of command, meant that brutality by the SNSs quickly spiralled out of control, upsetting senior officers mindful of the negative impact of atrocity stories, and was one of the reasons that they eventually curtailed and then closed down the unit. It is difficult uncovering the brutality inherent in military operations but the night-time actions of the SNSs are especially murky and 'wild', as will be discussed below. ${ }^{11}$ British SNS brutality prompted Jewish soldiers, taught them how to deal with insurgency and insurgents and set this within a colonial legal framework of collective punishment and punitive action that normalised draconian action.

\section{Intelligence Sharing}

The British army and Royal Air Force (RAF) special service officers (SSOs) who dealt with political-intelligence matters in the region collaborated from the outset of the Arab revolt with the Jews in Palestine for intelligence gathering, drawing on the Jews' good intelligence on the enemy, their Palestinian informers and their native Arabic-speakers. ${ }^{12}$ The SSOs ran intelligence in Palestine before the revolt and the army tapped into their expertise, using them for informers and field intelligence. For instance, in late 1936, Joshua Gordon was the Jewish Agency's liaison with the RAF intelligence officer in Nablus, Captain Windsor, known to the Jews as 'The Duke. ${ }^{13}$ In 1938, Windsor set up a meeting between the key Jewish agent Ezra Danin and army officer Captain Fitzpatrick, intelligence officer for the 9th Royal Hussars. Colonel Lash replaced Windsor, codenamed 'The Lion' by the Jews, and 
referenced as (later) Brigadier Norman Lash of Jordan's Arab Legion. ${ }^{14}$ J. P. Domville was another pivotal British SSO intelligence operative, who went on to serve in Iraq after December 1937. ${ }^{15}$ Reuven Zaslany (later Shiloah) was Domville's interpreter and they were friends well into the 1940s. The Jewish political leader, David Ben Gurion, met with Domville. Earlier, in 1934, Hos, another Jewish agent, had characterised Domville as the country's 'best Zionist informer on the English.' ${ }^{16}$ There was another SSO officer much used by the Jews, Hackett, Jews referring to him as A. Hackett-Fine, a phonetic transliteration from Hebrew, codenamed 'Khamis' and an MI5 or MI6 agent, who replaced Lash and with whom Danin was 'tight. ${ }^{17}$ Danin acted as arbiter between the police and the army on the value of captured intelligence, he decoded and translated Arabic documents, and the British even allowed him to interrogate captured rebels. ${ }^{18}$

The mutually beneficial relationship during the Arab revolt between the Jewish and British intelligence communities underpinned British military operations, and Wingate as an intelligence officer in Palestine from 1936 had established excellent relations with the Jewish intelligence branch, which would become Shai (Information Service) in 1940 and then military intelligence and Shabak (General Security Service) in 1948. Talking to one of Wingate's biographers many years later, King-Clark remembered that his superior officer had a 'secure intelligence network through the Jewish Agency. ${ }^{19}$ Mike Grove noted Wingate's contacts with the Jews, 'from the top downwards', including the future Israeli president, Chaim Weizmann: 'to the heads of all the settlements. They all knew Wingate. ${ }^{20}$ Danin had firm links to British intelligence officers and his 1944 published collection of captured Arabic documents bears resemblance to the reams of captured Arabic-language intelligence material stored in Wingate's microfilmed Palestine papers held in the British Library in London, much of which came from Jewish operatives. ${ }^{21}$ Wingate's Palestine papers prove that he was exchanging masses of secret documents with the Jews.

The Jews helped to direct British operations, as counterinsurgency demanded good intelligence and the Yishuv (the Jewish community in Palestine) had the upper hand here, as its intelligence on the Palestinians was so good. Jews also dressed in army uniforms on operations with the British, and British soldiers dressed as Jews in civilian clothes. ${ }^{22}$ The Jews and the British also encouraged Arab loyalist anti-rebel forces, a subject discussed in full elsewhere. ${ }^{23}$ Thus, Danin noted many years later that Pinhas Meital, a Jewish officer from Hadera, possibly in the police, mediated with the British for the return of loyalist Arabs to Palestine in $1938 .{ }^{24}$ Meanwhile, Jews such as David Hacohen of Haifa paid Arab loyalists. ${ }^{25}$ The Jews also supplied the anti-rebel Palestinian Nashashibi family with weapons; the issue is whether the British supplied these guns, via the Jews, which seems probable. ${ }^{26}$ The Jews looked to the British and to Palestinians willing to collaborate to achieve their aim of gathering intelligence, getting military training and weakening the Palestinians. The British were supporting the Yishuv with the strength of the British armed forcethe SNSs being one example-and in so doing gave men such as Danin access to the heart of the British military machine. Jewish intelligence infiltrated British security structures, stealing police files and so was better able to monitor Palestinian 
resistance. ${ }^{27}$ Similar things happened elsewhere in the British Empire, such as in Kenya in the 1950s, another colony with an articulate, non-native 'white' settler community, where the British handed over parts of their military operations to the settlers of the Kenya Regiment and the Kenya Police Reserve, units that committed the worst abuses against Mau Mau fighters. ${ }^{28}$ The SNSs grew from British-Jewish intelligence sharing.

\section{The British High Command and the Special Night Squads}

Wavell and Haining sanctioned the SNSs but army headquarters was ambivalent about irregular warfare and the employment of levels of force that were unjustifiable even by the draconian emergency laws in place at the time. There were official limits to pacification and Haining had urged his divisional commanders to punish 'unnecessary violence, vindictiveness which is un-British, killing in cold blood. ${ }^{29}$ As the army never instituted full martial law in Palestine, civil colonial officials still held sway and their protests were another friction on military excesses. One army intelligence officer recalled how a district commissioner (DC) - obviously Hugh Foot, the future Lord Caradon, who went on to become governor of Cyprus-warned a Palestinian village of a forthcoming army raid, and so a senior officer 'took the D.C. by the throat and shook him and called him a "bloody traitor". THE D.C. IS NOW LORD CARADON. $^{30}$ Foot saw at first-hand the effects of Wingate's work, as the latter 'wiped out opposition gangs by killing them all. He was taking sides. It was a dirty war of assassination and counter-assassination. I don't think we should have got mixed up in that. ${ }^{31}$ Evetts' brigade in Haifa was in charge of the SNSs' zone of operations and his local command protected Wingate's force from headquarters and from civil interference. Wingate and Evetts worked closely together, Evetts arranging for one of Wingate's informers to 'escape' police custody. ${ }^{32}$ Far from being a 'cowboy outfit', the SNSs were 'fully integrated' into 16th Brigade's counter-insurgency strategy. ${ }^{33}$ Evetts had a reputation for toughness towards Arab rebels: General Richard O'Connor, in command in Jerusalem, wrote to his wife in November 1938, how 'Jack Evetts has always (between ourselves) encouraged his men to be brutal, as being in the end more humane. I disagree with him over this. ${ }^{34}$ Evetts' harshness towards rebels chimed with Wingate's, Evetts already being a 'fan' of Wingate, both men willing to terrorise Palestinian villagers to force them to end support for the revolt. ${ }^{35}$ Evetts' divisional commander, General Bernard Montgomery, who arrived in Palestine towards the end of the life of the SNSs, shared this tough approach, leaving a local Anglican clergyman who was protesting about an army atrocity at the village of al-Bassa, 'absolutely bewildered', the senior colonial officer Edward Keith-Roach noted. 'To every question, he said, Monty had but one reply: "I shall shoot them." "The man is blood mad", the bishop moaned across my office table."36

Support from Evetts and the SNSs delighted the Yishuv, giving the Jews both a riposte to rebel terror attacks on Jewish settlements in Galilee and the opportunity for military training. Thus, one senior Jewish official thanked Evetts effusively when he left Palestine: 
We shall always gratefully remember your help, which has enabled us to be of some assistance to the British Army in its campaign. You, Brigadier Evetts, and your officers have exerted your utmost efforts to establish our reputation and improve our external appearance within the British Army, and for this we thank you most sincerely. We regret, however, that at the moment of your departure you are compelled to witness the passivity which has been imposed on us at a time when murder and attacks on property are still of almost daily occurrence. ${ }^{37}$

Israel well remembered the help afforded by Wingate and his men, and Israel's president welcomed Bredin and King-Clark when they went on a trip to the country in 1988. Bredin 'even had a hill named after him following one particularly spectacular exploit. ${ }^{38}$ Wingate - as 'sinister as ever' in King-Clark's remembrance- - started operations in June 1938 in 'great glee ... officially blessed and able to do as he want', a blessing that was eventually withdrawn, as the SNS operations turned so nasty and irregular that they offended the military high command, committing outrages that were systematic and systemic. ${ }^{39}$

\section{Terror in Galilee: A Dirty War}

Wingate and his men escalated and aggravated standard army counterinsurgency collective punishment practices directed at Palestinian villagers suspected of harbouring rebels, withholding information or being near insurgent attacks, such as the blowing up of the Iraq Petroleum Company oil pipeline or 'TAPline' that ran across Galilee to Haifa. Wingate told his men that they must strike hard in 'reprisal' attacks and on 11 June 1938 in one of the first operations, Bredin and his men chased an Arab band into a village and threw grenades into houses. ${ }^{40}$ The SNSs in their five-month operational life under Wingate from June to October 1938, and then under Bredin, carried out a set of outrages at Kfar Hittin (or Kafr Hattin), Hittin, Nin (or Nein), Kufur Masr (or Kafr Masr/Misr), Danna, Silat al-Dahr (pronounced Silat ed-Daher), Beisan (in Hebrew Beit She'an) and in and around Dabburiyya, alongside cumulative acts of extra-judicial brutality in unnamed villages. These all occurred in lower Galilee in the Jezreel Valley or near Tiberias, excepting that at Silat al-Dahr, located southwest of Jenin on the West Bank. The reference to the bayoneting at Khirbat Bayt Lidd towards the end of this article is surely a reference to Khirbat Lidd/Lydd in lower Galilee west of Afule, and not the settlement east of Netanya near Tel Aviv. The names of other villages where there were incidents, when transliterated from Arabic to Hebrew to English, make no sense or are not even Arabic sounding, such as Kokomble where the British threatened to force oil-sodden soil into villagers' mouths. ${ }^{41}$ In all these incidents, the argument is that Jewish fighters in the SNSs learned from their British comrades about inflicting violence, impressed by how British soldiers exercised imperial control, as their Hebrew-language personal accounts of their time with the SNSs attest. ${ }^{42}$ At Kfar Hittin, Bredin executed three prisoners brought to him by the Jews, proclaiming, "In the name of the King of England, I find you guilty of murder and sentence you to death"... He immediately ordered the English soldiers to carry out the sentence, and they shot the Arabs on the spot. 
In this, Bridden $[s i c]$ was following in the practices of Wingate. ${ }^{, 43}$ This might be a reference to an incident on 20 October 1938 witnessed by Jewish Sergeant Yigal Allon who had gone with Bredin to 'Hittin' where they shot a running Arab and captured three suspects and who 'on the way to the car they tried to escape and a squad shot them'. ${ }^{44}$ Wingate told Corporal Howbrook and the men serving under King-Clark that the Arabs were terrorising villagers, so his squad was 'to terrorise the terrorists kind of thing and catch them and just wipe them out. ${ }^{45}$ Bredin stood out in his actions, as King-Clark remembered:

Bala took a very tough line with the villagers near the pipeline- he could be a very
tough person, could Bala. In fact, some of the measures he took to prevent sabotage
were far from orthodox. On one occasion, in particular, when he took truly Draco-
nian action against a village which was harbouring gangsters, he very nearly came to
grief-but the result of his action was so successful in terms of preventing sub-
sequent sabotage, that his 'iron fist' method was conveniently filed away by
higher authority. ${ }^{6}$

As the squads moved closer to the settlers, they became embroiled; 'the deeper Wingate's policy took us into the Jewish camp, the more outside the law we became', was how King-Clark put it. ${ }^{47}$

The Palestine police picked up the dumped bodies of SNS assassinations in the south of the country, suggesting a zone of squad operations stretching beyond Galilee, or another 'dirty war' in southern Palestine. Police officer Richard Catling saw what he thought were 'remains' of the SNSs. When asked what he meant by this, he continued: 'I was still in Jaffa at the time. Certainly, on two occasions we picked up the bodies of dead Arabs that had been killed by these, this special unit ... In the rural area surrounding Jaffa. ${ }^{48}$ Such actions are reminiscent of the disposal of bodies by the French army during the Algerian insurgency in the 1950s or by Latin American armies later on. At times, dead Arabs were just 'villagers who got in the way', caught in indiscriminate shooting by squads entering villagers suspected of harbouring rebel fighters. ${ }^{49}$ The terror inflicted by the SNSs was of classical proportions: one favoured method used by British and Jewish soldiers alike in Galilee was that of the Roman legions-decimation, with variations on the proportion to be killed, and aimed at intelligence gathering, rifle gathering or simply to instil fear into local villagers. The Jews executed every eighth male villager in Kufur Masr (or Kafr Misr) to get them to hand over illegally held rifles. ${ }^{50}$ Bredin killed every 15 th man, three in total, in a village that failed to produce rifles, as recalled by a former Jewish fighter called Jonathan in the 1940s. ${ }^{51}$ Another group commanded by Bredin (Brodin in Hebrew) demanded seven rifles in 15 minutes and Bredin told villagers he would kill every tenth man if they were not forthcoming with the rifles, and the next time every eighth man. Brigade headquarters called Bredin in after this incident, after which he told his British and Jewish soldiers what to say in case of an official inquiry. ${ }^{52}$ Wingate also decimated villages. ${ }^{53}$ Palestinian villagers wrote a letter in English-composed by a lawyer, the Jews thought — complaining that Jewish supernumerary officers went into their village, lined up the men and shot every eighth man after not getting 
rifles. The Jews then said that they would return and kill everyone. This seems to have been an SNS unit but the murky mix of violence in Galilee with other British officers leading Jewish units and Jewish fighters acting unilaterally makes it difficult to decipher events. ${ }^{54}$

Jewish settlers and squad soldiers shared the officially sanctioned violence of the SNSs and they soaked up the accompanying training regimen. Wingate slapped and struck Jewish soldiers in the squads, who took this as a necessary part of their drill and called Wingate the 'insane one. ${ }^{55}$ Wingate never slapped British soldiers in the SNSs, an action that was contrary to British military law, his lieutenants telling him that they would never allow him to strike their men. ${ }^{56}$ The focus in the literature on the more famous Wingate detracts from the day-to-day lessons learnt by the Jews from British squad soldiers such as Bredin, about whom jumbled but consistent stories emerge of executions and brutality. ${ }^{57}$ After a massacre of unarmed Jewish civilians by rebels in Tiberias on 2 October 1938, the 'Jews also were in a mood for killing Arabs' and with British servicemen present turned machine guns on the villagers of Dabburiyya, on anyone entering or leaving the place and out in the open. ${ }^{58}$ Around Dabburiyya after the Tiberias massacre, SNS men shot random Palestinians, as when an 'Englishman' shot at an Arab by the village of Lubiya-possibly the villager on the bicycle below-but he was unable to hit him with his pistol so he got a rifle from a Jew and shot the man dead. ${ }^{59}$ The Tiberias massacre upset Bredin and he also organised his men for a retaliatory attack on a Bedouin camp near to Dabburiyya (or possibly in the Jordan valley) while aircraft machine-gunned their herds of animals. During the battle, a British officer from the Trans-Jordan Frontier Force arrived and started to fire indiscriminately into Bedouin tents. ${ }^{60}$ Bredin may not have been a committed Zionist but he was attached to the Jews with whom he served. On the way to Dabburiyya after the Tiberias massacre, Bredin and his men

met an Arab riding his bicycle. Breeden [sic] shot him dead-this helped a bit in reviving the general atmosphere. When we arrived at Dabourria [sic] Breeden gave orders not to have mercy and not behave like gentlemen .... I remember that at the sight of a Jewish family, mother and children burnt in the Tiberias fire, tears ran down Breeden's cheeks and he said: 'Would I be allowed to take revenge, I would have eliminated all the Arabs. ${ }^{61}$

Wingate attacked Dabburiyya after the Tiberias massacre, possibly in the same attack detailed above, while Haganah intelligence later pinpointed Kfar Hittin as responsible for the Tiberias massacre prompting a punitive raid by Bredin. ${ }^{62}$ Squad soldiers also provoked incidents, as when a Jewish soldier in the SNSs saw the force turn machine guns on Arabs who had come out to extinguish a gasoline-induced fire started by the SNS, killing 20. He also remembered how money seized from gang leaders was taken for Jewish use, including a 'slap-up' meal in Afule. ${ }^{63}$ The Jewish fighter, Shlomo, recalled how five soldiers, two Jews, two British and a British officer, went to the village of Danna after a pipeline attack, possibly on 11 June 1938, in an undercover operation in civilian clothes on a rainy, muddy day, Shlomo remembering that the inclement weather annoyed the officer. At the village, the officer casually shot all 
men who were running. He then gathered the surviving villagers and asked Shlomo how many lashes he thought a man could take. Shlomo replied with the figure of 25 , to which the officer said that he would give each villager 13 lashes. The British officer then whipped all the villagers except the mukhtar (the headman) and a child. The officer also 'tortured' one Palestinian to obtain information on the gangs 'in a cruel manner ... it was a horrible sight. ${ }^{64}$ As the officer whipped villagers, village women begged him to stop and kissed his feet, crying out. Another Jew remembered a lecture to Danna villagers from Wingate, who spoke Arabic, and villagers being whipped as they ran away. ${ }^{65}$ Perhaps the officer angry at the muddy weather was Wingate, which seems odd considering his well-known, remarkable willingness to bear long marches and rough field conditions. The SNSs targeted villages for multiple raids, Zwi Brenner-another future Israeli military leader-watching as Wingate ordered the villagers of Danna 'to open their mouths and ordered the English soldiers to force into their mouths earth soaked in the oil which had poured from the pipeline. Here, too, Wingate made sure that those who carried this out were English soldiersand not the Jews. ${ }^{66}$ Shlomo and the British also found two Arabs wounded and dying, and they conducted 'a field trial right there and killed them both. ${ }^{67}$ Mundane, nonlethal punishments were also commonplace. Thus, Wingate humiliated local villagers, making the men of a village run 10-15 kilometres

in front of slowly driving army vehicles. The Arabs who were usually exhausted after such an 'exercise' had then to go all the way back on foot.... In some instances Wingate lined up the Arabs in front of the pipeline, and forced them to wash their faces with the layer that had formed on the surface of the earth, after the pipeline was set on fire. The layer consisted of burning oil mixed with the stones and dirt, and when the Arabs hesitated to obey his orders, there were always soldiers, who saw to it that Wingate's instructions were carried out. ${ }^{68}$

Howbrook was present at a TAPline rupture where no villager would talk

So Wingate said, 'Right, we'll teach these so-and-so's a lesson.' So we got all the men in the village. Oh, outside the ... . where the oil had been burnt there's a big pool of black oil burnt. And we got all the men by the side of this. And then we took an arm and a leg each and flung them all into the middle of it. ${ }^{69}$

The use of oil as a torture for villagers appears in biographies of Wingate, too, with Wingate forcing sand into villagers' mouths until they vomited. ${ }^{70}$

Wingate turned to one of the Jews and, pointing to the coughing and spluttering Arab, said 'Shoot this man.' The Jew looked at him questioningly and hesitated. Wingate said, in a tense voice, 'Did you hear? Shoot him.' The Jew shot the Arab. The others stared for a moment, in stupefaction, at the dead body at their feet. The boys from Hanita were watching in silence. 'Now speak', said Wingate. They spoke. $^{71}$

Arabs who looked 'suspect' risked beatings and death if caught by the SNSs, as when a British SNS corporal captured a man at night near the village of Nin (or Nein) who started begging as he had a weapon on him: 'killed on the spot' and his body taken to the police. ${ }^{72}$ 
The SNSs were the most visible collaboration between the army and the Yishuv but police units would collaborate with Jewish settlers, as when British police officer Jack Binsley saw British soldiers go with a Jewish police inspector to the Jewish settlement of Zichron Yaakov after an Arab attack. Binsley subsequently came across the bodies of six bayoneted Arab men from a local village on a threshing-room floor in a large grain store, 'Dreadful wounds in their chests and stomachs.' The settlers had primed the soldiers with food and drink, after which they 'rushed' a local village even though there was no evidence that any attack had come from there, and they selected six probable bandits to be bayoneted. 'The real murderer was the inspector though he had used my countrymen to carry out his dirty work, knowing that the matter would be hushed up to avoid a scandal involving British troops', wrote Binsley. ${ }^{73}$ The SNSs were not remarkable in leaving wounded rebels to die on the battlefield: 'Well, just leave them. When they got shot it was their fault. ${ }^{74}$

British support emboldened Jewish forces, especially supernumerary police, armed and supported by the British, to fight rebels across Palestine and not just in Galilee. One British colonial official, A. T. O. Lees, saw Jewish police in trucks enter the village of Sarafand al-Kharab near Jaffa:

They met the first year little boys from the village school who were just proceeding from school on their way home. A member of the police hurled a bomb at the little boys which exploded and killed three of them, two being aged six years each and one aged seven. The Jews continued their drive, and when passing near the Mosque one of them fired his rifle at a person who was praying and killed him. Another Jew fired one shot at a woman carrying her grandchild (aged under two years). The shot killed the grandmother, while the child was injured and taken to hospital. ${ }^{75}$

Lees' account supports Catling's memory of assassinations in southern Palestine near Jaffa. Jewish supernumerary police threatened Lees with a 'Tommy gun' and barred his way, after which he heard gunfire:

I heard more bursts of firing which were immediately followed by shrill wails of fem-
inine anguish proceeding from the direction of the big Arab house. Not long after-
wards two or three frantic Arab women from the house burst in upon us,
incoherently explaining that the Jews were upon them and had shot, or were shoot-
ing, every man they could find ... we heard the sound of the lorry departing. ${ }^{76}$

Lees then called the police who arrived and took away two wounded Arabs; the Jewish police had shot and carried away other men in their lorry. Lees visited the two Arabs in hospital two days later, on 24 October 1938, and the 'Arab Medical Officer in charge, seeing that I was interested in this wanton attempted murder, mentioned that similar cases were admitted almost daily. ${ }^{77}$ Lees reported these cases to police and the civil authorities but nothing happened.

British military confidence and prowess impressed the Jews in the SNSs. One Jewish squad fighter, Chaim Levkov, saw how Bredin commanded the battlefield. 'Here we found an Arab with a rifle and we killed him; there we found an Arab and we suspected he had a rifle, and we killed him.' After a battle in Dabburiyya, Levkov and his unit found an Arab who had survived the battle, hidden in some straw, begging for his 
life. The Jews hit him until a British soldier came and removed his 'bayonet from his rifle and began making a salad of the Arab'. Wingate asked for details of the incident and his only complaint was that the Arab had died before he could interrogate him. ${ }^{78}$ Dan Ram, another Jewish SNS fighter, remarked how the British 'were wonderful soldiers' before saying '[b]ut when they were angry there was no limit to their', at which point his sentence ends with an exclamatory sigh sounding like 'hrmmph.79 Wingate and the British in their short collaboration with the Jews passed on their counterinsurgency operational method. Ram described Bredin as a 'wonderful man'; on one village 'punishment raid', Bredin told the Jews to stay out as they would have to live with these people afterwards and so Bredin went in with British troops alone. ${ }^{80}$

Bredin used Jewish Haganah intelligence intercepts in October 1938, when SNS troops went to the village of Silat al-Dahr after a pipeline attack and where they chose three villagers, 'Lufti el Yousef, Mohammed el Youssef and Rashid Ibrahim el Kassem [Lutfi al-Yusuf, Muhammad al-Yusuf, Rashid Ibrahim al-Qasim], and took them out 30 metres from the village. There they were tied, shot and they are dead. ${ }^{\prime 81}$ King-Clark remembered this incident in correspondence many years later with one of Wingate's biographers:

You mentioned to me the incident in Palestine which got Bala Bredin into trouble, the reprisals he exacted after a particular attack on the pipeline. I was looking at some of my notes on Wingate's Palestine papers the other day and read of three men being shot at the village of Silat el Daher [Silat al-Dahr] in October $1938 .^{82}$

King-Clark felt that Bredin and his 'wild' behaviour helped force the closure of the SNSs after Wingate's departure:
Bala could be very tough and uncompromising, ably supported by his 'Wild Geese.' In fact, he got so tough with one village on the pipeline that he very nearly got into real trouble. But it stopped the conflagrations and this saved his bacon! (I'll tell you about it sometime.) When Wingate left (in Sep 38?) and Bala carried on, his squad got a bit Wild West and out of hand and I think that was one of the reasons the SNS closed down. ${ }^{83}$

The British Army fought 'terror with terror. ${ }^{84}$ Wingate put Palestinian villagers in a position of being more afraid of soldiers than rebels. If rebel-gang tracks led to a village then Wingate's men burnt down barns, arrested villagers, seized cattle and when villagers said 'Commander, sir, what can we do? The gang members come to us armed, and we are weaponless, and can only surrender to their demands', Wingate replied: 'Two choices: either you be afraid of me and then you can fight the gangs. I don't accept the claim that you are poor and can't do anything. ${ }^{85}$ Wingate admitted that said that it was not villagers' fault, 'but that is not the question. I want to reach a situation where the residents of the village will not allow foreigners to enter their village. ${ }^{\text {, }}$

The SNS planned raids using intelligence, or they reacted to events with 'wild' violence, as happened at the Tiberias massacre. Thus, when a rebel mine killed the Jewish leader of Ein Harod settlement, Chaim Sturman, on 14 September 1938, Wingate let 
out a 'cry, more a scream than an order' and inflicted 'the most severe retaliation' on the Arab quarter of Beisan (Beit She'an), near the explosion:

'Everybody into the cars!' .... We grabbed our rifles and within a few seconds were all in the cars. Without any plan of action or preparation, with Wingate at our head, we entered the Arab part of Beit Shean, which swarmed with gang members, and began to beat and trample anyone in our path. Wingate himself went out of control, entering stores and destroying whatever was in them. An hour later we returned to Ein Harod. ${ }^{87}$

Sympathetic biographers gloss over Wingate's ordering 'the killing of every Arab discovered in the vicinity of the raid' on Beisan, pointing to his emotional state and the 'wild inconsidered orders made in the heat of the moment' before attacking Beisan and so 'some innocent loiterers were shot among fleeing rebels who returned fire. It was a sudden unprepared raid, a mistake on Wingate's part, uncharacteristic of his teaching. ${ }^{88}$

Wingate and his squads launched prepared and reactive punishment raids, as the situation demanded, and Wingate's volatile temper prompted casual impromptu violence towards Arabs as at Beisan or when Jewish operatives were speaking with an old Palestinian with trachoma and a limp who worked for them as a spy, with a view to using him as a guide for a village raid. Wingate demanded "ffetch me this Arab" ... and the spy was brought to him. He stepped very close to him, fixed him with his eyes, and began to question him in Arabic. Suddenly he stepped back and dealt the Arab a heavy blow across the neck which felled him to the ground. ${ }^{89}$ King-Clark hit one local man so hard during a raid on Tilleil (presumably Tuleil) on Lake Huleh that he broke his hand. ${ }^{90}$ Even when raids were prepared following intelligence leads, unplanned 'wild' violence could erupt. Thus, in early September 1938, Wingate had intelligence that incriminated the mukhtar of Tantura, so he went with a squad to the village and rounded up villagers to find the guilty man. The raid then turned nasty, as one of his biographers recounts, with a soldier forced to shoot a fleeing villager: 'Then while Wingate was going down the line examining the prisoners one of them dashed away and fled and was instantly shot by a squadsman. '91 'Shot trying to escape' was a convenient euphemism for assassinations, one of the Jewish soldiers present, Levkov, recalling that Wingate went to Tantura and shot an innocent Arab by accident, a local man who was also in the Jewish trade union Histadrut. Levkov also accused British officers of being drunk in action, after Wingate had left the squads. ${ }^{92}$

\section{The End of the SNSs}

The regular army was not shy of using violence against rebels and the closure of the SNSs concerned the proper governance of Palestine and the formal regulation and justification of force as much as it was about opposition to the use of excess force. Wingate operated off the official grid and the army and police were uncomfortable with 'swashbuckling' special units that were 'free and easy' in their attitude to regular forces, as King-Clark noted in his memoirs: 
The Army, traditionally, viewed us with the suspicion it reserves for 'private armies' - with a tinge, perhaps, of envy at our being 'outside the law' and of respect at the results we were achieving .... As far as the Palestine Police were concerned ... we were in trouble very early on, due to the liberties we took in entering-and sometimes searching-Arab villages without warning and with no police escort. At the very beginning - in June-a policemen did sometimes accompany us on patrol, but as we became fitter and they didn't, they soon disappeared from the SNS scene. We didn't really blame them, however, since their life work was the non-partisan maintenance of civil law and order operating from police stations and posts throughout the country. In their eyes, in contrast, we must have appeared as a very fly-by-night biased organisation. ${ }^{93}$

Senior Jewish officials were surprised that Wingate survived as long as he did in Palestine, convinced that everyone was against him except Wavell and 'Ritchi', presumably the RAF intelligence chief at army headquarters, Alan Ritchie. ${ }^{94}$ Evetts' support was also vitally necessary in the face of other local regimental commanders in Galilee who were unhappy with what the SNSs were doing. ${ }^{95}$ That King-Clark and his fellow British squad members showed off about their successes against rebels earned them few friends outside the Yishuv:

To be fair to the Army and Police, the antipathy they felt towards the SNS was justifiably aggravated by the fact that we became rather swollen-headed about our imagined toughness and our 'killing rate.' We did get very bumptious towards the end and there were one or two cases of 'Wild West, six-shooter' exuberance foreign to normal British Army behaviour-but good fun nevertheless-(with Bala Bredin's 'Wild Geese' well to the fore). I think GHQ was wise to send Wingate home and close the whole thing down - for a number of reasons, including the 'private army' angle-when it did. ${ }^{96}$

By September 1938, Haining had made up his mind to tell Evetts to close down the SNS units, just as the Munich settlement on Czechoslovakia freed up masses of regular British troops for deployment to Palestine. Once the Munich crisis had passed and British troops were not needed for a European war, the SNSs were surplus to needs. Without the Munich settlement of September 1938, the SNSs might have survived, General William Ironside, commander of Middle East forces in 1939, writing to Wingate about how if the Czechoslovakia crisis 'had developed I had made up my mind to arm the Jews and to withdraw most of my troops.97

Support for the SNSs was always partial and the army and Foreign Office had never countenanced the creation of Jewish-only units, as units such as these would have been a diplomatic disaster for British relations with the wider Arab world. The War Office in London wrote to General John Dill, GOC Palestine and so Wavell's predecessor, in February 1937, following a conference on Palestine, informing him how

The Foreign Office representative at the conference made it quite clear that they would view with the gravest apprehension any idea of using the Jews in offensive operations against the Arabs. They foresaw that this might drive the whole of the Arabs together, and result in a general conflagration in Iraq and elsewhere. There would be no objection to using the Jews in a defensive role in their own localities, but not in the Arab localities. ${ }^{98}$ 
Wavell heeded this advice when he agreed to the formation of the British-led SNSs in early 1938, but some squads eventually operated at times as Jewish-only units, as settler-soldiers became more confident in their martial skills. Haining had less time for Wingate than his mentor, Wavell. Moreover, Wingate's superiors may not have understood fully what was going on in Galilee, at least in the first few months of SNS operations when the whole of Palestine was in turmoil, central command in Jerusalem was focused on other things and reports were not yet in on SNS operations. ${ }^{99}$ Certainly, the high command 'knew perfectly well' that its soldiers were training Jews but chose to ignore this while it suited them, giving the SNSs a short window of opportunity that was then closed. ${ }^{100}$ Pressure against the SNSs soon mounted within the British establishment in Palestine. Not just civil officials and police, but many British intelligence officers objected to Wingate's harsh policies, convinced that they alienated the Arabs. A convention of British intelligence officers in the north of Palestine at the end of January 1939 agreed not to employ Jews as this provoked the Palestinians, a decision that annoyed Wingate but about which he could do little but protest as his squads were now on the decline. ${ }^{101}$ The British authorities also suspected Wingate of leaking intelligence to the Yishuv so they bugged his telephone and made his life 'unbearable. ${ }^{102}$ British intelligence monitoring extended to Wingate's wife and her mother, possibly the result of an army investigation into an 'execution' order given by Wingate to Jewish soldiers in an Arab village. ${ }^{103}$ Haining praised Wingate after the latter had left Palestine, but saw his bias to the Zionist cause as so great 'as to render his services in the Intelligence Branch nugatory and embarrassing. His removal to another sphere of action has been timely. ${ }^{104}$ Wingate's 'thuggery' threatened to ruin the proper governance of Palestine, as local civil administrators recognised: 'the people he was bumping off, any odd Arabs who happened to go into the village at night, they weren't necessarily men who were blowing up the pipeline. ${ }^{\prime 105}$ British colonial government in Palestine was never strong financially or militarily and it relied on forms of local consent that local administrators had to manage after the soldiers had gone. ${ }^{106}$ The SNSs were victims of their own success, their rampant violence that cowed the Palestinians ultimately offending the sensibilities of the British military high command, which shied away from absolute irregular force in favour of moderated regular force, and so closed the squads and dismissed Wingate.

\section{'Passing It On'}

Intuitively, one would expect the many Jews trained by Wingate to learn from his methods, and those of the British army, the experts in colonial pacification. Wingate was idiosyncratic and passionate-Bredin saw in Wingate the 'fervour of a fanatic', while another British official who worked with Wingate in Sudan described him as a 'dangerous madman'-but his basic approach to countering rebels was that of the army, as it was with officers like Bredin and King-Clark. ${ }^{107}$ That said, the SNSs pushed British counter-insurgency to an unrestrained extreme, making any form of normal relations with Palestinians impossible. The future commander 
of the Haganah strike force, the Palmach, Yitzhak Sadeh, noted this, writing in June 1938 how the 'way these squads operate (searching in village accompanied by beatings etc.) could, according to the opinion of several people from this region complicate us in undesirable relations with the neighbours. ${ }^{108}$ What this article does not discuss is how some Jews thought Wingate to be more trouble than he was worth. ${ }^{109}$ Wingate passed on to the Jews levels of unrestrained violence not easily used by regular British soldiers but which were routine in the SNSs. The SNSs forged future Israeli military supreme commanders such as Moshe Dayan, who served with Wingate and was impressed by his 'utter ruthlessness' and willingness to shoot Arabs 'on the spot to make an example to others' and whose 'affection' for Wingate 'knew no bounds. The Haganah men called him Hayedid (the Friend) and realised there was a lot to be said for his conviction that the best defence was attack. ${ }^{110}$ James Pollock, a district commissioner, put it more bluntly: 'Wingate taught the Jews blood-letting and they've never looked back.' ${ }^{111}$ Dayan wrote later how, while early Jewish military leaders such as Sadeh implanted more aggressive, commando thinking among Jewish fighters, what really impressed Dayan was Wingate's 'professionalism' that came from his British army training. Wingate had 'positiveness, a stubborn lack of compromise. A dominating personality he infected us all with his fanaticism and faith. ${ }^{112}$ Wingate's aim was to create a Jewish army, telling Haganah men,

\begin{abstract}
'You will now listen very carefully to what I am going to say to you, and you will never forget my words. Today is a memorable day for the people of Israel, for today you see the beginning of the Jewish Army'.... These were words which even the Hagana men didn't utter out loud. But that was exactly what Captain Orde Wingate had in mind. ${ }^{113}$
\end{abstract}

Wingate's legacy endured in the Yishuv long after his departure from Palestine. Harry Levin, besieged in Jewish west Jerusalem in May 1948, wrote in his diary of that 'strange, lovable Englishman' Wingate, who 'laid the foundations' of the Palmach, a force then fighting to lift the siege of the city. ${ }^{114}$ Wingate passed on tactical training through the SNSs but also at the higher levels an active, aggressive spirit, and as a 'professional officer of the British army, his views carried great weight with the political leaders in charge of the Haganah.' ${ }^{115}$ Wingate's exacting SNS training regime, with its long route marches, in which he struck Jewish recruits in the face- 'they appeared to lap it up' remembered Bredin-brutalised Jewish soldiers and normalised violence, as does any recruit boot camp for elite military units. ${ }^{116}$ British soldiers such as Corporal Howbrook serving with King-Clark's squad had been through bounded, established British military training, and in his time with the SNS he saw the eccentric Wingate treat the Jews 'almost like dirt ... the rank and file he could do anything with them. He could push them around and order them about. And they'd almost run like kittens, little puppies. ${ }^{117}$

The British taught the Jews to use cold steel in action against Arab rebels, to go in with the bayonet, the ultimate act of personal killing, as at Khirbat Lidd/Lyd (often Khirbat Bayt Lidd) with King-Clark's squad in September 1938 where soldiers could see an Arab hiding behind a wall. King-Clark called in his nearest Jewish soldiers: 
I think it was David from Deganiya [presumably Kibbutz Degania Bet south of Lake Tiberias], and made bayonet-fighting motions with my arms. I remember his eyes widening as he pointed to his fixed bayonet. I nodded vigorously, he took off and we watched as he ran the fifty yards to the wall, jumped on it and repeatedly stabbed down on the far side with his rifle and bayonet. A minute later he was back at my side, an old Mauser rifle in his free hand, his own bayonet blooded to the hilt, his eyes wide with the shock of what he had just done. ${ }^{118}$

Haganah units joined in this attack, or another attack at a different time directed at the same village, including future Israeli commanders Yigal Allon, Shimon Avidan and Moshe Dayan, where, tellingly, British troops had to stop Jewish fighters in the SNSs beating Palestinians and looting their houses. ${ }^{119}$

\section{Conclusion}

The study here of the British army's use of the Special Night Squads is a case study of how imperial powers will use an indigenous loyalist colonial community to help pacify rebels. The empirical detail of the brutality of the squads is striking but not surprising, as the British military empowered and mobilised local settlers with a visceral stake in Palestine's future, as would happen in other colonies such as Kenya in the 1950s. The British army was conservative as an institution and ambivalent when it came to irregular war in the style of the SNSs, and so eventually closed down the squads after a short, partial operational life, one marred by egregious atrocities that offended the sensibilities of the British high command, local civil officials and other army officers. Central military control managed and mediated the violence of pacification, and in counterinsurgencies the use of 'special forces' invariably came up against military hierarchies suspicious of soldiers operating independently, justifiably worried about accusations concerning out-of-control death squads and 'dirty wars'. Wavell agreed to the formation of the SNSs, but the inspiration for the squads came from Wingate, and locally from commanders such as Evetts, bypassing central military command structures except for the initial agreement to create what was then a new unknown force, proving the power of local initiatives when it came to counterinsurgency. The basic tactics of the SNSs were those of the British army, with collective punishment for local hostile populations who were supporting armed insurgents, tactics that became starkly visible when crudely employed by unorthodox military units such as the SNSs whose commander, Wingate, did nothing to hide the inherent violence of counterinsurgency.

\section{Acknowledgements}

The author acknowledges the Trustees of the Liddell Hart Centre for Military Archives for reproduction of material held at the Centre; Brunel University for funding for a research trip to Israeli municipal archives in 2015; and Itamar Radai for help with transliterated Arabic and Hebrew material. 


\section{Notes}

Readers will allow some imprecision in the use of 'Yishuv', 'Zionists', 'Jewish' and 'Jews' in this article, all of which will refer to the Jewish community in Palestine before 1948; in some contexts, the use of 'Jews/Jewish' suits the language employed at the time and is unavoidable if imprecise. Similar comment applies to the mixed use of 'Arabs' and 'Palestinians'.

[1] For Cyprus, see French, Fighting EOKA, 118.

[2] Lefen, Ha'Shai, 273.

[3] 'Bala' Bredin led irregular ' $X$ ' squads in Cyprus in the 1950s, also known as the 'Toads', with turned EOKA fighters. French, Fighting EOKA, 147-48.

[4] Royle, Orde Wingate, 119.

[5] Bierman and Smith, Fire in the Night, 71.

[6] Eyal, 'The Arab Revolt, 1936-1939, 33.

[7] 2nd Battalion The West Yorkshire Regiment, Battalion Intelligence Summaries, Nos 5-7, Ramallah, 17 Nov.-1 Dec. 1938, The Prince of Wales's Own Regiment of Yorkshire Museum, York.

[8] Statement of Jewish Agency (hereafter JA), Views to Chief Secretary to the High Commissioner, 25 Aug. 1938 (in English), given after interview with Chief Secretary on 24 Aug., The Riots: Negotiations with the Government, Feb. 1936-June 1936 (Aug. 1938), File 04/165-B/622, Tel Aviv Municipal Archive, City Hall, Tel Aviv.

[9] For British practice and doctrine on counterinsurgency, see Callwell, Small Wars; Gwynn, Imperial Policing; Simson, British Rule and Rebellion.

[10] King-Clark, Free for a Blast, 146.

[11] For brutality, see Hughes, 'The Banality of Brutality', 313-54.

[12] Gelber, Sorshey ha-Havatzelet, 149-64.

[13] Danin, Tsiyoni be-kol Tnay, 135-36.

[14] Ibid., 135-36; Lefen, Ha'Shai, 44. The Air Force List records a Flying Officer N. O. Lash in November 1938, in Middle East command, presumably the same Lash, and someone who went on to command in Jordan's Arab Legion in 1948.

[15] Air Force List, July-Sept, 1930, Sept. 1937, Dec. 1937-Jan. 1938.

[16] Friling, Arrows in the Dark, vol. 1, 279-80.

[17] Lefen, Ha'Shai, 44; Danin, Tsiyoni be-Kol Tnay, 135-36, 163.

[18] Gelber, Sorshey ha-Havatzelet, 164.

[19] R. King-Clark to Trevor Royle, 22 Feb. 1993, MR4/17/307/1/4, Tameside Local Studies and Archive Centre (hereafter TLSAC), Ashton-under-Lyne.

[20] M. R. L. Grove, 4510/03, 23, Imperial War Museum Sound Archive (hereafter IWMSA). Wingate also dealt closely with Moshe Shertok (Sharett) of the JA's Arab political department and Eliyahu Golomb of Haganah. Royle, Orde Wingate, 130.

[21] Danin, Te'udot u-Dmuyot me-Ginzey ha-Knufiyot ha-Arviyot; Wingate Papers, M2313, British Library (hereafter BL), London; Gelber, Sorshey ha-Havatzelet, 164.

[22] Dekel, Shai, 202-03; and Slutsky, Sefer Toldot ha'Haganah, 919-20.

[23] Cohen, Tzva ha-Tzlalim [An Army of Shadows]; and Hughes, 'Palestinian Collaboration with the British'.

[24] Danin, Tsiyoni be-Kol Tnay, 141.

[25] CID Intelligence Summary 92/38, Jerusalem, 31 Dec. 1938, S25/22732, Central Zionist Archive (hereafter CZA), Jerusalem.

[26] Cohen, Army of Shadows, passim; and Elyashar, Li-Hyot im Falastinim, 65-70.

[27] Lefen, Ha'Shai, 49ff. The Haganah archive in Tel Aviv stores many stolen English-language Palestine police files.

[28] Elkins, Britain's Gulag, passim.

[29] Townshend, 'In Aid of the Civil Power', 32. 
[30] Lt-Col. Tony Simonds, Memoir, 'Pieces of War', 163, Simonds papers, 08/46/1, Imperial War Museum Documents (hereafter IWMD).

[31] Interview with Lord Caradon (Hugh Foot), Lever Arch File 55, Wingate and SNS, 11, Thames TV Material, Imperial War Museum Film Archive (hereafter IWMFA).

[32] Morton, Just the Job, 85.

[33] Royle, Orde Wingate, 122.

[34] Letter, O'Connor to wife, 2-3 Nov. 1938, O'Connor papers, 3/1/8, Liddell Hart Centre for Military Archives (hereafter LHCMA).

[35] Bierman and Smith, Fire in the Night, 89-90.

[36] Keith-Roach, Pasha of Jerusalem, 194-95.

[37] Undated note, S25/8151-21, CZA.

[38] Joseph Finklestone, 'Stalkers in the Night', Jewish Chronicle, June 1988, in MR4/17/307/1/7, TLSAC.

[39] Lt-Col. R. King-Clark, Special Night Squad, Personal Diary with Training Notes by Wingate in Some Experiences in Palestine. Ex the Lorettonian, 22 June 1938, 11, King-Clark papers, 83/ 10/1, IWMD; King-Clark, Free for a Blast, 181-82.

[40] Slutsky, Sefer Toldot ha'Haganah, 919-20.

[41] Chaim Levkov, Testimonies of Special Night Squad fighters (in Hebrew), made c. 1941-44, S25/10685, CZA.

[42] Ibid.

[43] Eshkol, A Common Soldier, 173.

[44] Letter, Yigal Allon to Jewish Supernumerary police in Afule (details of Operations, 20 Oct. 1938), 26 Oct. 1938, S25/8768, CZA.

[45] Fred Howbrook, 4619/03, 4, IWMSA.

[46] King-Clark, Free for a Blast, 187.

[47] Ibid., 177.

[48] Quotation from Sir Richard Catling, 10392/9/4, 16-17, IWMSA.

[49] King-Clark, Free for a Blast, 191.

[50] el-Nimr, 'The Arab Revolt in Palestine', 112.

[51] Jonathan, Testimonies of Special Night Squad fighters [in Hebrew], made c. 1941-44, S25/ 10685, CZA.

[52] Note from 'A.A.', 19-20 Nov. 1938, S25/8768, CZA.

[53] Ben-Eliezer, The Making of Israeli Militarism, 26-27.

[54] Note from 'A.A.', 19-20 Nov. 1938, S25/8768, CZA.

[55] Tzvi, Testimonies of Special Night Squad fighters [in Hebrew], made c. 1941-44, S25/10685, CZA.

[56] Maj-Gen. H. E. N. Bredin, 4550/05, 30, IWMSA.

[57] Arieh (Aryeh?), Testimonies of Special Night Squad fighters [in Hebrew], made c. 1941-44, S25/10685, CZA.

[58] Ibid.

[59] Ibid.

[60] Chaim Levkov, ibid.

[61] Untitled Reminiscence: Operations Tiberias and Tabor [by Levacov, presumably Levkov], 56, Alice Hay of Seaton Papers, John Rylands Library Manuscripts, Manchester (hereafter JRL).

[62] Eshkol, A Common Soldier, 169, 172

[63] Chaim Levkov, Testimonies of Special Night Squad fighters [in Hebrew], made c. 1941-44, S25/10685, CZA.

[64] Shlomo, ibid.

[65] Chaim Levkov, ibid.

[66] Eshkol, A Common Soldier, 174. 
[67] Shlomo, Testimonies of Special Night Squad fighters [in Hebrew], made c. 1941-44, S25/ 10685, CZA.

[68] Meeting with Mr Tabori and Gershon Ritov, 27 March 1950, 8, Alice Hay of Seaton Papers, JRL.

[69] Howbrook, 4619/03, 36, IWMSA.

[70] Mosley, Gideon Goes to War, 44-45, 58. See also Eshkol, A Common Soldier, 174-76.

[71] Mosley, Gideon Goes to War, 44-45, 58. For more on oil being forced into villagers' mouths, see also Chaim Levkov, Testimonies of Special Night Squad fighters [in Hebrew], made $c$. 1941-44, S25/10685, CZA.

[72] Operations of Patrols of Englishmen and Jews, 13 June 1938, 26/6: Reports on Fosh Actions, Haganah Archive, Tel Aviv.

[73] Binsley, Palestine Police Service, 104-05.

[74] Howbrook, 4619/03, 35, IWMSA.

[75] Extract from a letter from an English Friend in Palestine, 11 Jan. 1939, Lees Papers, 5/9, LHCMA.

[76] Memoir by Lees entitled 'Unbeaten Track: Some Vicissitudes in Two Years of a Public Servant's Life by el-Asi', Lees Papers, 5/13, 3-4, LHCMA. Lees used the nom de plume al-'Asi, the Arabic name of the River Orontes, also meaning 'a rebel'.

[77] Ibid.

[78] Chaim Levkov, Testimonies of Special Night Squad fighters [in Hebrew], made c. 1941-44, S25/10685, CZA.

[79] Dan Ram, 21699, IWMSA.

[80] Ibid.

[81] Quoted in Bierman and Smith, Fire in the Night, 114-15, 125. Compare this to the material in the Wingate papers, where a captured Arab document details how a British patrol came to the village of Silat al-Dahr and killed the three men listed: Youssef Abu Dura, Pamphlet of the Great Leader of the fighters on British Atrocities, 14 Oct. 1938, Wingate papers, 72, M2313, BL.

[82] Letter, Colin Smith to King-Clark, 7 Sept. 1997, MR4/307/1/9, TLSAC.

[83] Letter, King-Clark to Trevor Royle, 22 Feb. 1993, MR4/17/307/1/4, TLSAC.

[84] Strachan, Politics of the British Army, 169.

[85] Danin, Tsiyoni be-Kol Tnay, 140.

[86] Eshkol, A Common Soldier, 174-76.

[87] Bierman and Smith, Fire in the Night, 114-15; and Eshkol, A Common Soldier, 175.

[88] Ben-Eliezer, The Making of Israeli Militarism, 26-27; Sykes, Orde Wingate, 169.

[89] Mosley, Gideon Goes to War, 56.

[90] Lt-Col. R. King-Clark, Special Night Squad, Personal Diary with Training Notes by Wingate in Some Experiences in Palestine. Ex the Lorettonian, 23 June 1938, 13, King-Clark papers, 83/ 10/1, IWMD.

[91] Sykes, Orde Wingate, 177. See also Bierman and Smith, Fire in the Night, 113, in which a Jewish soldier shot dead the mukhtar as he tried to run away.

[92] Chaim Levkov, Testimonies of Special Night Squad fighters in Hebrew], made c. 1941-44, S25/10685, CZA.

[93] King-Clark, Free for a Blast, 177-78.

[94] Meeting with Moshe Sharret and Reuven Shiloah, 17-18, Alice Hay of Seaton Papers, JRL. There was also a Colonel N. M. Ritchie in Palestine at the time, in command of the King's Own Royal Regiment.

[95] Eshkol, A Common Soldier, 160.

[96] King-Clark, Free for a Blast, 178.

[97] Ironside (Gibraltar, Government House) to Wingate, 8 June [1939?], Wingate papers, appendix, M2313, BL. 
[98] Letter, Deverell (War Office, London) to Dill (Palestine), 19 Feb. 1937, Dill papers, 2/9, LHCMA.

[99] Smith, 'Two Revolts in Palestine', 92-94; and Townshend, 'In Aid of the Civil Power', 31.

[100] Colonel F. Morgan in 'Arab Rebellion' section, Lever Arch File 55, Thames TV Material, IWMFA.

[101] Slutsky, Sefer Toldot ha'Haganah, 936.

[102] Rossetto, 'Maj-Gen Orde Charles, 52; and Taslitt, Soldier of Israel, 66.

[103] Mosley, Gideon Goes to War, 56.

[104] Remarks of General Haining [written by W. C. Ritchie?] on Captain Wingate, 10 July 1939, originally dated 22 July 1938, extracted from Army Form B. 194, Wingate papers, appendix, M2313, BL.

[105] Charles Evans, Lever Arch File 55, Thames TV Material, IWMFA.

[106] David French, The British Way in Counter-Insurgency, passim for fragile nature of the colonial state.

[107] Maj-Gen. H. E. N. Bredin, 4550/05, 31, IWMSA; letter, A. E. Vicars-Miles to King-Clark, 28 Dec. 1988, MR4/17/307/1/12, TLSAC.

[108] Slutsky, Sefer Toldot ha'Haganah, 1237, note to 921.

[109] See, Anglim Orde Wingate and the British Army, 59.

[110] Slater, Warrior Statesman, 45.

[111] James Pollock in 'Orde Wingate and SNS' section, Lever Arch File 55, Thames TV Material, IWMFA.

[112] Dayan, Story of My Life, 29-30.

[113] Taslitt, Soldier of Israel, 61.

[114] Levin, Jerusalem Embattled, 132-35 (8-9 May 1948).

[115] Luttwak and Horowitz, The Israeli Army, 1948-1973, 16.

[116] Maj-Gen. H. E. N. Bredin, 4550/05, 30, IWMSA.

[117] Fred Howbrook, 4619/03, 23, IWMSA.

[118] King-Clark, Free for a Blast, 198.

[119] Eshkol, A Common Soldier, 165; letter, Lieberman to Jewish Agency, Foreign Affairs, 9 Sept. 1938, S25/8768, CZA.

\section{References}

Anglim, Simon. Orde Wingate and the British Army, 1922-44. London: Pickering \& Chatto, 2010. Ben-Eliezer, Uri. The Making of Israeli Militarism. Bloomington, IN: Indiana University Press, 1998. Bierman, John and Colin Smith. Fire in the Night: Wingate of Burma, Ethiopia and Zion. New York: Random House, 1999.

Binsley, Jack. Palestine Police Service. Montreux: Minerva, 1996.

Callwell, C. E. Small Wars: Their Principles and Practices. London: HMSO, 1906 [1896].

Cohen, Hillel. Tzva ha-Tzlalim [An Army of Shadows]. Jerusalem, 'Ivrit Publishing, 2004; Army of Shadows: Palestinian Collaboration with Zionism, 1917-1948, translated by Haim Watzman. Berkeley, CA: University of California Press, 2008.

Danin, Ezra. Te'udot u-Dmuyot me-Ginzey ha-Knufiyot ha-Arviyot, 1936-39 [Documents and Portraits from the Arab Gangs Archives in the Arab Revolt in Palestine, 1936-39]. Jerusalem: Magnes, 1981 [1944].

Danin, Ezra. Tsiyoni be-kol Tnay [Zionist under any Condition]. Jerusalem: Kidum, 1987.

Dayan, Moshe. The Story of My Life. London: Weidenfeld \& Nicolson, 1976.

Dekel, Efraim. Shai: The Exploits of Hagana Intelligence. New York: Yoseloff, 1959.

Elkins, Caroline. Britain's Gulag: The Brutal End of Empire in Kenya. London: Cape, 2005.

el-Nimr, Sonia Fathi. 'The Arab Revolt in Palestine: A Study Based on Oral Sources.' PhD thesis, University of Exeter, 1990. 
Elyashar, Eliyahu. Li-Hyot im Falastinim [To Live with Palestinians]. Jerusalem: Sephardic Community Committee, 1975.

Eshkol, Yosef. A Common Soldier: The Story of Zwi Brenner. Tel Aviv: MoD Books, 1993.

Eyal, Yigal. 'The Arab Revolt, 1936-1939: A Turning Point in the Struggle over Palestine.' In A NeverEnding Conflict: A Guide to Israeli Military History, edited by Mordechai Bar-Ond. Westport, CT, and London: Praeger, 2004.

French, David. The British Way in Counter-Insurgency, 1945-67. Oxford: Oxford University Press, 2011.

French, David. Fighting EOKA: The British Counter-Insurgency on Cyprus, 1955-59. Oxford: Oxford University Press, 2015.

Friling, Tuvia. Arrows in the Dark: David Ben-Gurion, the Yishuv Leadership and Rescue Attempts during the Holocaust. 2 vols. Madison, WI: University of Wisconsin Press, 2005.

Gelber, Yoav. Sorshey ha-Havatzelet: ha-Modi'in ba-Yishuv, 1918-1947 [Growing a Budding Fleurde-Lis: The Intelligence Forces of the Jewish Yishuv in Palestine, 1918-47]. Tel Aviv: Misrad ha-Bitahon, 1992.

Gwynn, Charles W. Imperial Policing. London: Macmillan, 1934.

Hughes, Matthew. 'The Banality of Brutality: British Armed Forces and the Repression of the Arab Revolt in Palestine, 1936-39.' English Historical Review 124, no. 507 (2009): 313-354

Hughes, Matthew. 'Palestinian Collaboration with the British: The Peace Bands and the Arab Revolt in Palestine, 1936-39.' Journal of Contemporary History (2015). doi:10.1177/ 0022009415572401.

Keith-Roach, Edward. Pasha of Jerusalem: Memoirs of a District Commissioner under the British Mandate, edited by Paul Eedle. London: Radcliffe, 1994.

King-Clark, R. Free for a Blast. London: Grenville, 1988.

Lefen, Asa. Ha'Shai: Shorasheha Shel Kehilat ha'Modi'in ha'Israelit [The Roots of the Israeli Intelligence Community]. Tel Aviv: Ministry of Defence, 1997.

Levin, Harry. Jerusalem Embattled: A Diary of the City under Siege. London: Cassell, 1997 [1950].

Luttwak, E. and D. Horowitz. The Israeli Army, 1948-1973. Cambridge, MA: Abt Books, 1983 [1975].

Morton, Geoffrey. Just the Job: Some Experiences of a Colonial Policeman. London: Hodder \& Stoughton, 1957.

Mosley, Leonard. Gideon Goes to War. London: Barker, 1955.

Rossetto, L. 'Maj-Gen Orde Charles Wingate and the Development of Long-Range Penetration.' PhD thesis: Kansas State University, 1982.

Royle, Trevor. Orde Wingate. London: Weidenfeld \& Nicolson, 1995.

Simson, H. J. British Rule and Rebellion. Edinburgh and London: Blackwood, 1937.

Slater, Robert. Warrior Statesman: The Life of Moshe Dayan. London: Robson, 1992.

Slutsky, Yehuda, ed. Sefer Toldot ha'Haganah [Book of the History of the Haganah], Vol. 2, Parts 2-3, Me'Haganah le'ma'avak [From Defence to Struggle]. Tel Aviv: Ma'arachot, 1963.

Smith, Charles. 'Two Revolts in Palestine: An Examination of the British Response to Arab and Jewish Rebellion, 1936-1948.' PhD thesis, University of Cambridge, 1989.

Strachan, Hew. The Politics of the British Army. Oxford: Clarendon Press, 1997.

Sykes, Christopher. Orde Wingate. London: Collins, 1959.

Taslitt, Israel. Soldier of Israel: The Story of General Moshe Dayan. New York: Funk \& Wagnalls, 1969.

Townshend, Charles. 'In Aid of the Civil Power: Britain, Ireland and Palestine, 1916-1948.' In Counterinsurgency in Modern Warfare, edited by Daniel Marston and Carter Malkasian. Oxford: Osprey, 2008. 